\title{
KOMUNIKASI POLITIK CALON KETUA DPD PDI PERJUANGAN DALAM KONFERENSI DAERAH DPD PDI PERJUANGAN JAW A BARAT
}

\author{
Adiyana Slamet $^{1}$, Wahyu Khanoris ${ }^{2}$ \\ Program Studi I Imu K omunikasi Univer sitas K omputer Indonesia, Fakultas I Imu Sosial dan I Imu Politik \\ Universitas K omputer Indonesia Dipati Ukur N0. 102-110 Lt. 9 Bandung $40132^{1,2}$ \\ adiyana.slamet@email.unikom.ac.id $^{1}$ \\ khanoris@gmail.com ${ }^{2}$
}

\begin{abstract}
This study intends to determine the depth of the Political Communication Region Conference DPD PDIP West J ava, with a focus Political Communication Youngest Candidate Chairman Region Conference DPD PDIP in West J ava Period 2015-2020. To describe the focus of the study, the researchers divided into several sub-micro problem, namely, the process of political communication and the realities of political communication. This research method is qualitative interactive methods, Case Study. Subjects in this study amounted to 6 (six) people, obtained through purposive sampling technique. The technique of collecting data through interviews, observation, documentation and library Studies. Testing techniques to test the validity of data credibility by triangualisation and membercheck. The results showed that, the process of political communication Political Comunication Younger Chairman Candidate DPD PDI Perjuangan West $J$ ava Region Conference of DPD PDI Perjuangan West J ava is a series of events that occur when Branch Conference, recruitment and screening and final stage is region conference. At all stage of political communication performed by youngest candidate for chairman using the PDI-P Party Structural and personal to the DPC and the PAC as well as the communication to the DPP. By using structural and personal youngest candidate for chairman easier to conduct political communication. The reality of political communication that occurs when region conference PDI-P West J ava was held is appear name of Abdy Yuhana within three (3) major candidates for chairman of the PDI-P, West J ava. As well as chairman of the youngest candidate gets 69 sound recommendation of DPC and PAC. Conclusion of The process of political communication Political Comunication Younger Chairman Candidate DPD PDI Perjuangan West J ava Region Conference of DPD PDI Perjuangan West J ava that the process of political communication occurs when branch conference, recruitment and screening, and the final is region conference that happened so dynamic, in which youngest candidates chairman doing political communication by utilizing the structural hierarchy of the party and personal. The reality of Political Comunication Younger Chairman C andidate D PD PDI Perjuangan West I ava Region Conference of DPD PDI Perjuangan West Java appear name of candidates as the youngest chairman as three candidates recommended by the DPP. Following the unanimously council, TB.Hassanudin elected as Chairman, Abdy Yuhana as secretary and Aang Hamid Suganda as Vice Chairman.
\end{abstract}

Keywords: Political Communication, Chairman Candidate, Region Conference, DPD PDI Perjuangan West J ava.

\begin{abstract}
Abstrak
Penelitian ini bermaksud untuk mengetahuai secara mendalam tentang Komunikasi Politik Calon Ketua Termuda DPD PDI Perjuangan dalam Konfrensi daerah DPD PDI Perjuangan Jawa Barat Periode 2015-2020. Untuk menjabarkan fokus penelitian, maka peneliti membagi ke dalam beberapa sub-sub masalah mikro yaitu, proses komunikasi politik dan realitas komunikasi politik. Metode penelitian ini adalah metode kualitatif dengan menggunakan desain penelitian Studi Kasus. Subjek dalam penelitian ini berjumlah 6 (enam) orang, yang diperoleh melalui teknik purposive sampling. Teknik pengumpulan data melalui Wawancara, Observasi, Dokumentasi dan Studi Pustaka. Teknik uji keabsahan data dengan uji credibility dengan cara triangualisasi, dan membercheck. Hasil penelitian bahwa, Proses komunikasi politik Komunikasi Politik Calon Ketua Termuda DPD PDI Perjuangan dalam Konfrensi daerah DPD PDI Perjuangan Jawa Barat Periode 2015-2020 merupakan sebuah rentetan kejadian yang terjadi saat konfecab, penjaringan \& penyaringan dan terakhir tahap konfrensi daerah. Pada semua tahap komunikasi politik yang dilakukan oleh calon ketua termuda mengunakan Struktural Partai PDI Perjuangan dan personal ke DPC \& PAC serta komunikasi ke DPP. Dengan mengunakan Struktural dan personal calon ketua termuda lebih mudah untuk melakukan komunikasi politiknya.
\end{abstract}


Realitas komunikasi politik yang terjadi saat Konfrensi daerah DPD PDI Perjuangan Jawa Barat yaitu menculnya nama Abdy Yuhana dalam 3 (tiga) besar calon ketua DPD PDI Perjuangan Jawa Barat. Serta calon ketua termuda mendapat 69 suara rekomendasi dari DPC dan PAC. Simpulan Proses komunikasi politik Komunikasi Politik Calon Ketua Termuda DPD PDI Perjuangan dalam Konfrensi daerah DPD PDI Perjuangan Jawa Barat Periode 2015-2020, bahwa proses komunikasi politik terjadi pada saat konfercab, penjaringan dan penyaringan dan terakhir yaitu Konfrensi daerah yang terjadi begitu dinamis, dimana calon ketua termuda melakukan komunikasi politik dengan memanfaatkan hierarki struktural partai dan personal. Realitas Komunikasi Politik DPD PDI Perjuangan Jawa Barat munculnya nama calon ketua termuda sebagai ketiga calon ketua yang direkomendasikan oleh DPP. Setelah dilakukan nya Musyawarah mufakat terpilihlah TB.Hassanudin sebagai Ketua, Abdy Yuhana sebagai Sekertaris dan Aang Hamid Suganda sebagai Wakil Ketua.

Kata Kunci: Komunikasi Politik, Konfrensi daerah, Ketua DPD PDI Perjuangan Jawa Barat 


\section{Pendahuluan}

Komunikasi politk yang dibangun oleh salah satu kandidat calon dalam merancang strategi untuk mendapat dukungan dan kepercayaan dari para kader PAC dan DPC, guna menduduki posisi ketua merupakan suatu proses bangunan komunikasi politik yang dilakukan secara terus-menerus oleh salah satu calon kandidat untuk mencapai dan mendapat dukungan serta memenuhi target politiknya. Komunikasi Politik sebagai kegiatan politik merupakan penyampaian pesan-pesan yang bercirikan politik oleh aktor-aktor politik kepada pihak lain. Kegiatan ini bersifat empirik, karena dilakukan secara nyata dalam kehidupan sosial dan komunikasi politik dilakukan saat kegiatan politik dalam sistem politik.

Bangunan komunikasi politik yang dilakukan dengan terus menjaga hubungan baik, keterbukaan informasi dan membangun kepercayaan antar kader merupakan hal yang sangat penting bagi calon ketua untuk mendapatkan suatu dukungan dari para kaderkader partai. Karena seorang organisatoris harus pandai dalam menjaga hubungan baik dengan berkomunikasi kepada para kader. Pesan politik akan membentuk opini secara internal ditubuh Partai Politik dalam momentum politik,. Hal ini komunikasi politik menjadi penting karena proses pemilihan ketua DPD PDI Perjuangan Jawa Barat bagaimana meyakinkan di tubuh partai itu sendiri

Pemilihan calon ketua DPD PDI Perjuangan Jawa Barat melibatkan seluruh elemen partai PDI Perjuangan dari tingkatan Dewan Pimpinan Cabang (PAC), Dewan Pimpinan Cabang (DPC), Dewan Pimpinan Daerah (DPD) dan sampai tingkatan Dewan Pimpinan Pusat (DPP). Semua elemen ikut andil dan mempunyai peranan masing-masing tentu yang diatur di anggaran dasar/anggaran rumah tangga yang disingkat dengan AD/ART dan surat keputusan (SK) dari Partai PDI Perjuangan.
Pergantian ketua silih berganti dalam sebuah Partai Politik merupakan sebuah tradisi lima tahunan yang dilakukan oleh Partai Demokrasi Indonesia Perjuangan, pergantian tersebut merupakan keharusan yang terus dilakukan Partai Demokrasi Indonesia Perjuangan guna untuk mejalankan AD/ART dan amanat organisasi dalam menjaga regenerasi dan kestabilan suatu partai politik.

Momentum pemilihan calon ketua ditingkatan DPD adalah pemilihan yang dilakukan ditingkatan Provinsi yang dilakukan oleh kader-kader partai untuk melanjutkan tongkat estafet kepemimpinan partai ditingkatan provinsi untuk melakukan regenerasi dan menggantikan kepengurusan yang lama dengan kepengurusan yang baru.

Musyawarah mufakat dalam ajang suatu pemilihan baik ditingkatan Pengurus Anak Cabang (PAC), Dewan Pimpinan Cabang (DPC), Dewan Pimpinan Daerah (DPD) dan Dewan Pimpinan Pusat (DPP) merupakan suatu prinsip yang pertama kali dilakukan oleh Partai Demokrasi Indonesia Perjuangan pada tahun 2015 dalam melakukan pemilihan calon ketua dan kewajiban organisasi, musyawarah mufakat merupakan suatu yang baru dalam kubu partai PDI Perjuangan untuk mengindikasikan partai ini kearah moderenitas tetapi tidak menghilangkan nilainilai atau prinsip dari Pancasila itu sendiri. Peneliti mengajak untuk menilik kebelakang dimana dalam pemilihan calon ketua dari tingkatan PAC, DPC hingga DPD, PDI Perjuangan menggunakan system one man one vote dari tahun 2000, 2005 dan 2010.

Kecendrungan para kandidat calon ketua yang rata-rata berumur 50 tahun keatas untuk mencalonkan ketua DPD PDI Perjuangan khususnya Jawa Barat, ketika ada salah satu kandidat calon yang berumur dibawah 40 tahun merupakan suatu hal yang tidak lumrah. Karena kalau melihat fakta terdahulu dalam pemilihan calon ketua DPD PDI Perjuangan Jawa Barat dari periode tahun 2000, 2005, 2010 dan sampai ke tahun 2015 ada satu kandidat yang lebih muda ketika pemilihan 
calon ketua DPD PDI Perjuangan Jawa Barat periode 2015-2020.

Tabel $\mathrm{K}$ andidat $\mathrm{C}$ alon $\mathrm{K}$ etua DPD PDI Perjuangan J awa Barat Tabel 1.1

K omparasi Calon K etua DPD PDI

Perjuangan J awa Barat periode 2000, 2005, $2010 \mathrm{~s} / \mathrm{d} 2015$

\begin{tabular}{|c|c|c|}
\hline $\begin{array}{c}\text { Periode } \\
\text { Pencalonan } \\
\text { Calon } \\
\text { K etua DPD } \\
\text { PDIP J awa } \\
\text { Barat }\end{array}$ & $\begin{array}{c}\text { Nama Calon } \\
\text { K etua DPD } \\
\text { PDIP J awa } \\
\text { Barat }\end{array}$ & $\begin{array}{c}\text { Umur } \\
\text { Kandidat } \\
\text { Calon K etua } \\
\text { DPD PDIP } \\
\text { J awa Barat }\end{array}$ \\
\hline $\begin{array}{c}\text { Pemiihan } \\
\text { Calon Ketua } \\
\text { DPD PDIP } \\
\text { Jabar } \\
\text { Periode } \\
\text { 2000-2005 } \\
\end{array}$ & $\begin{array}{l}\text { 1. Rudi Harsa } \\
\text { Tanaya } \\
\text { 2. Endang } \\
\text { Karman } \\
\text { 3. M uchtar } \\
\text { Budiana } \\
\end{array}$ & $\begin{array}{l}50 \\
60 \\
60\end{array}$ \\
\hline $\begin{array}{c}\text { Pemiihan } \\
\text { Calon Ketua } \\
\text { DPD PDIP } \\
\text { Jabar } \\
\text { Periode } \\
2005-2010 \\
\end{array}$ & $\begin{array}{l}\text { 1. Rudi Harsa } \\
\text { Tanaya } \\
\text { (Catatan: } \\
\text { M enang } \\
\text { Aklamasi) }\end{array}$ & 55 \\
\hline $\begin{array}{c}\text { Pemiihan } \\
\text { Calon Ketua } \\
\text { DPD PDIP } \\
\text { Jabar } \\
\text { Periode } \\
2010-2015 \\
\end{array}$ & $\begin{array}{ll}\text { 1. } & \text { Rudi Harsa } \\
\text { Tanaya } \\
\text { 2. Eka } \\
\text { Prasetya } \\
\text { 3. Yadi } \\
\text { Srimulyadi }\end{array}$ & $\begin{array}{l}60 \\
50 \\
50\end{array}$ \\
\hline $\begin{array}{c}\text { Pemiihan } \\
\text { Calon Ketua } \\
\text { DPD PDI } \\
\text { Perjuangan } \\
\text { Jabar } \\
\text { Periode } \\
2015-2020\end{array}$ & $\begin{array}{ll}\text { 1. } & \text { TB } \\
\text { Hasanudin } \\
\text { 2. A Ady } \\
\text { Y uhana } \\
\text { 3. Aang } \\
\text { Hamid } \\
\text { Suganda }\end{array}$ & $\begin{array}{l}60 \\
38 \\
70\end{array}$ \\
\hline
\end{tabular}

Sumber: Arsip DPD PDI Perjuangan Jawa Barat 2015

\section{K erangka Pemikiran}

\subsection{Pengertian K omunikasi Politik}

Komunikasi Politik sebagai kegiatan politik merupakan penyampaian pesan-pesan yang bercirikan politik oleh aktor-aktor politik kepada pihak lain. Kegiatan ini bersifat empirik, karena dilakukan secara nyata dalam kehidupan sosial. Sedangkan sebagai kegiatan ilmiah, komunikasi politik adalah salah satu kegiatan politik dalam sistem politik (Maswadi Rauf,1993: 32- 33).

Menurut Rush dan Althoff (1997:255)

Komunikasi politik adalah transmisi informasi yang relevan secara politis dari satu bagian sistem politik merupakan unsur dinamis dari suatu sistem politik; dan proses sosialisasi, partisipasi serta rekrutmen politik bergantung pada komunikasi. Secara sederhana unsur-unsur tersebut dapat digambarkan sebagai berikut:

\section{Gambar 2.1}

Sistem Politik dalam K omunikasi Politik (Rush and Athhoff)

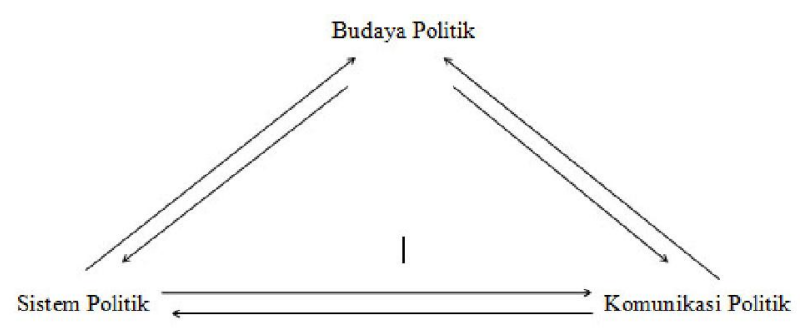

Komunikasi politik adalah salah satu dari tujuh fungsi yang dijalankan oleh setiap sistem politik. Dalam kata-kata Almond sendiri:

"All of the functions performed in the political system - political socialization and recruitment, interest articulation, interest aggregation, rule making, rule application, and rule adjudication - are performed by means of communication."

Dalam buku The Politics of The Development Areas, pada tahun 1960. Almond berpendapat bahwa:

"komunikasi politik adalah salah satu fungsi yang selalu ada dalam setiap sistem politik sehingga terbuka kemungkinan bagi para ilmuwan politik untuk memperbandingkan berbagai 
sistem politik dengan latar belakang budaya yang berbeda (Maswadi Rauf, 1993: 21).

Faktor tujuan dalam komunikasi politik itu, jelas pula tampak pada definisi yang diketengahkan oleh Lord Windlesham dalam karyanya, What is political communication adalah:

"Komunikasi politik adalah suatu penyampaian pesan politik yang secara sengaja dilakukan oleh komunikator kepada komunikan dengan tujuan membuat komunikasi berperilaku tertentu (Effendy, 2002: 158)."

"Menurut Dan Nimmo (2005: 8) "komunikasi Politik yaitu (kegiatan) komunikasi yang dianggap komunikasi politik berdasarkan konsekuensi konsekuensinya (aktual maupun potensial) yang mengatur perbuatan manusia di dalam kondisi-kondisi konflik. “

Dengan demikian, inti komunikasi politik adalah komunikasi yang diarahkan kepada pencapaian suatu pengaruh sedemikian rupa, sehingga masalah yang dibahas oleh jenis kegiatan komunikasi tersebut dapat mengikat suatu kelompok atau warga tertentu. Komunikasi politik dengan demikian adalah upaya sekelompok manusia yang mempunyai orientasi, pemikiran politik atau ideology tertentu dalam rangka menguasai atau memperoleh kekuasaan.

Komunikasi politik merupakan proses penyampaian pesan-pesan yang terjadi pada saat fungsi-fungsi itu dijalankan. Hal ini berarti bahwa fungsi komunikasi politik terdapat secara inherent di dalam setiap fungsi sistem politik.

Dari beberapa pendapat mengenai komunikasi politik tersebut, dapat disimpulkan bahwa komunikasi politik merupakan suatu penyampaian pesan politik antara pemerintah, partai politik, dan juga warga masyarakat untuk menyampaikan ide, gagasan, dan pemikiran yang dapat mempengaruhi seluruh elemen masyarakat untuk dapat mengikat semua warganya melalui suatu sanksi yang telah ditentukan bersama. Jadi, dilihat dari sistem dan pengertian komunikasi politik di atas komunikasi politik merupakan suatu proses penyampaian informasi atau pesan yang dilakukan oleh pimpinan partai politik terhadap anggota partai politik dengan saluran/media berupa lisan maupun tulisan dan diharapkan anggota partai politik tersebut mengerti dan menyetujui dari apa yang telah disampaikan.

\subsection{Politik}

Politik adalah kegiatan yang menyangkut cara bagaimana kelompokkelompok mencapai keputusan-keputusan yang bersifat kolektif dan mengikat melalui usaha untuk mendamaikan perbedaanperbedaan diantara anggota-anggotanya (Hague et al dalam Budiardjo, 2008:16).

Sedangkan menurut Roelofs dalam buku Dan Nimmo, Politik adalah pembicaraan atau lebih tepat, kegiatan politik (berpolitik) adalah berbicara. Roelofs menekankan bahwa politik tidak hanya pembicaraan, juga tidak semua pembicaraan adalah politik. Akan tetapi, "hakekat pengalaman politik dan bukan hanya kondisi dasarnya ialah bahwa ia adalah kegiatan berkomunikasi antar orang.

Sedangkan pelaksanaan tujuan diantaranya berupa penyusunan kebijakan umum yang menyangkut distribusi dan alokasi atas sumber daya yang ada dalam negara. Untuk melaksanakan kebijakan itu perlu adanya kekuasaan (power) dan kewenangan (authority). Dengan demikian konsep pokok dalam politik meliputi negara (state), kekuasaan (power), pengambilan keputusan (decision making), kebijakan (policy), serta pembagian atau alokasi (distribution or allocation). 


\subsection{Proses K omunikasi Politik}

Proses adalah arus, perubahan dan ketidaktepatan dalam hubungan kegiatan terhadap satu sama lain. Barlund melukisakan sifat proses itu sendiri berkembang, dinamis, sinambung, sirkular, tak dapat diulang, tak dapat dibalikan dan kompleks. Sebagai proses, komunikasi tidak memiliki titik bertolak; tiada hentinya ia meliputi interpretasi personal, pertukaran sosial dan politik. Ia tidak memiliki penyebab yang mudah dilihat bagi akibatnya yang dapat diamati. (Dan Nimmo. 2005)

Miriam Budiardjo, dalam bukunya Dasar-Dasar Ilmu Politik, menjelaskan bahwa proses politik adalah pola-pola politik yang dibuat oleh manusia dalam mengatur hubungan antara satu sama lain. Proses dalam setiap sistem dapat dijelaskan sebagai input dan output. Input itu sendiri merupakan tuntutan serta aspirasi masyarakat dan juga dukungan dari masyarakat. Input ini kemudian diolah menjadi output, kebijaksanaan, dan keputusan-keputusan, yang akan dipengaruhi oleh lingkungan sosial.

Dari beberapa penjelasan dari ilmuwan politik yang menjelaskan tentang proses politik, maka dapat disimpulkan bahwa Pokok dari politik adalah upaya untuk mencapai tujuan, dan untuk mencapainya harus ada proses yang dilewati yang kemudian disebut sebagai proses politik. Secara garis besar, proses politik adalah semua interaksi yang terjadi dalam sebuah sistem politik. Proses politik dimulai dari adanya tuntutan untuk memenuhi tujuan dan kepentingan politik yang tentunya terdapat instrument untuk memperjuangkan tuntutannya. Proses politik merupakan tahapan setelah adanya input politik dimana proses mencakup serangkaian tindakan pengambilan keputusan, baik oleh perorangan, kelompok, maupun lembaga apapun macam legislatif, eksekutif, maupun yudikatif dan lain-lain dalam rangka memenuhi tujuan atau kepentingannya. Harus diketahui bagaimana input politik itu terbentuk dan bergerak, sebab dinamikanya akan sangat berpengaruh terhadap output politik atau setelah melalui proses politik. Oleh karena itu harus dikenali tenaga-tenaga pembuat atau tenaga pembantu dari input tersebut.

\subsection{M omentum Politik}

Gun-gun dalam bukunya "Dinamika Komunikasi Politik" menjabarkan: "Momentum adalah pesan politik itu sendiri. Saat elit memainkan "the game of words" dengan menyatakan seribu kata manis dan saling mengapresiasi lawan politiknya, substansi pertarungan sesungguhnya dapat kita temukan dimomentum yang menjadi latar tindakan actor"

\subsection{R ealitas K omunikasi Politik}

Realitas Komunikasi Politik adalah sebuah sistem yang konstan, teratur dan dapat diramalkan, misalnya sebagai:

1. Pertukaran informasi melalui pelaksanaan kekuasaan (Ken Goldstein).

2. Interaksi antara elite, media warga negara mengenai topik-topik yang berkaitan dengan politik (Talia Stroud).

3. Pertukaran gagasan dan pesan, verbal atau visual, secara langsung atau bermedia, dalam suatu ruang publik yang dapat diidentifikasi, yang tujuannya dan konsekuensinya adalah untuk mengubah struktural atau produk pemerintah atau menghindari perubahan tersebut (Lynn Sanders). (Mulyana, Deddy, Komunikasi Politik, Poltik Komunikasi, 2013, 7)

\section{M etode Penelitian}

Dalam Penelitian ini peneliti menggunakan pendekatan kualitatif dengan desain studi kasus, mengacu pada John W.Creswell dalam bukunya Qualitative Inquiry and Research Design: Choosing Among Five Tradition bahwa studi kasus 
sebuah eksplorasi dari suatu sistem yang terikat atau suatu kasus/beragam kasus yang dari waktu ke waktu melalui pengumpulan data yang mendalam serta melibatkan berbagai sumber informasi yang kaya dalam suatu konteks. Sistem terikat ini diikat oleh waktu dan tempat sedangkan kasus dapat dikaji dari suatu program, peristiwa, aktivitas atau suatu individu dan organisasi. Dengan perkataan lain, studi kasus merupakan penelitian dimana peneliti menggali suatu fenomena tertentu (kasus) dalam suatu waktu dan kegiatan (program, even, proses, institusi atau kelompok sosial) serta mengumpulkan informasi secara terinci dan mendalam dengan menggunakan berbagai prosedur pengumpulan data selama periode tertentu. Selanjutnya John W.Creswell mengungkapkan bahwa apabila kita akan memilih studi untuk suatu kasus, dapat dipilih dari beberapa program studi atau sebuah program studi dengan menggunakan berbagai sumber informasi yang meliputi observasi, wawancara, materi audio-visual, dokumentasi dan laporan. Konteks kasus dapat "mensituasikan" kasus di dalam settingnya yang terdiri dari setting fisik maupun setting sosial, sejarah atau setting ekonomi. Sedangkan fokus di dalam suatu kasus dapat dilihat dari keunikannya, memerlukan suatu studi (studi kasus intrinsik) atau dapat pula menjadi suatu isu (isu-isu) dengan menggunakan kasus sebagai instrumen untuk menggambarkan isu tersebut (studi kasus instrumental). Ketika suatu kasus diteliti lebih dari satu kasus hendaknya mengacu pada studi kasus kolektif. Untuk itu Lincoln Guba mengungkapkan bahwa struktur studi kasus terdiri dari masalah, konsteks, isu dan pelajaran yang dipelajari. (Creswell, 1998: 61).

\section{Hasil Penelitian \& Pembahasan Pembahasan}

4.1 Proses Komunikasi Politik Calon K etua Dalam K onfrensi daerah DPD PDI Perjuangan J awa Barat

Proses komunikasi politik calon ketua termuda dalam melakukan komunikasi poltiknya kepada kader partai yang ada di daerah dengan memanfaatkan struktural partai untuk membangun komunikasi politik dengan mengunakan momemtun-momentum politik seperti Pileg (Pemilihan Legislatif), Pilpres (Pemilihan Presiden), momemtum tersebut digunakan oleh calon ketua termuda untuk melakukan komunikasi serta membangun kepercayaan terhadap kader partai yang didaerah khusunya Jawa Barat. Selain untuk membangun komunikasi dan kepercayaan terhadap kader, calon ketua termuda juga menghimpun dukungan kepada kader yang ada di daerah agar suara rekomendasi untuk calon ketua termuda ini mendulang tinggi.

Bangunan komunikasi yang dibangun oleh calon ketua termuda tergolong unik, dimana calon ketua termuda mengedepankan pola komunikasi politik secara personal dengan kepercayaan dan bertukar informasi, dimana dalam membentuk suatu kepercayaan calon ketua termuda melakukan komunikasi secara simultan dari jauh-jauh hari sebelum diadakannya Konfrensi daerah DPD PDI Perjuangan Jawa Barat. Dalam bertukar informasi ketua termuda juga mengunakan komunikasi dengan kader didaerah dengan menyampaikan informasi-informasi yang ada kepentingannya dengan partai PDI Perjuangan khususnya didaerah Jawa Barat guna untuk membangun partai PDI Perjuangan yang terbaik kedepannya.

Komunikasi politik dalam pemilihan Konfrensi daerah DPD PDIP Jawa Barat adalah sebuah rentetan kegiatan dari Konfrensi cabang, Penjaringan \& Penyaringan dan Konfrenasi daerah (Konfrensi daerah) DPD PDIP Jawa Barat. Konfrensi cabang diselenggarakan di Jawa Barat pada tanggal 9 maret 2015 yang 
dilaksanakan di tiga kota/kabupaten Bandung, Cirebon dan Kerawang. Untuk kegiatan Penjaringan dan Penyaringan dilaksanakan dikantor DPD PDI Perjuangan Jawa Barat. Serta Konfrensi daerah DPD PDIP Jawa Barat Periode 2015-2020. dilaksanakan di hotel horison Bandung.

Saluran dalam menyampaikan pesan komunikasi politik yang dilakukan oleh calon ketua termuda dalam Konfrensi daerah DPD PDI Perjuangan Jawa Barat yaitu dengan mengunakan saluran yang pertama Struktural Organisasi Partai dan yang kedua Secara Personal. Dengan menggunakan kedua pendekatan tersebut calon ketua termuda lebih gampang dalam melakukan komunikasi politiknya. Terbukti dengan kedua pendekatan tadi calon ketua termuda bisa mendapatkan dukungan dari kader partai yang ada di daerah seperti DPC dan PAC.

Peneliti dalam penelitian ini mencoba menguriakan komunikasi politik yang digunakan oleh calon ketua termuda dalam prosesnya dengan menggunakan komunikasi politik melalui saluran yang pertama Struktural Partai, dengan menggunakan komunikasi politik melalui struktural partai yaitu dengan memanfaatkan momentummomemtum Pemilihan Legislatif, Pemilihan Presiden, Pemilihan Gubernur, Pemilihan Kepala Daerah dan Agenda-agenda internal partai lainnya. Yang kedua komunikasi politik yang dilakukan oleh calon ketua termuda melalui saluran Personal dimana dengan mengunakan hubungan personal calon ketua termuda bisa melakukan komunikasi politik kepada kader-kader partai yang ada di daerah yaitu dengan menggunakan Keterbukaan Calon, Bertukar Informasi dan kepercayaan.

Dua pendekatan komunikasi politik yang dilakukan oleh calon ketua termuda dengan menggunakan Struktural Partai dan Personal terbukti berhasil dalam melakukan pendekatan terhadap kader-kader partai yang ada di daerah. Dengan mendapatkan suara rekomendasi dari DPC dan PAC yaitu sebesar enam puluh sembilan (69) suara, dengan mendapatkan suara rekomendasi sebanyak itu calon ketua termuda tergolong berhasil dalam melakukan komunikasi politiknya dan mendapatkan dukungan dari kader-kader partai yang ada didaerah seperti DPC dan PAC.

Proses komunikasi politik dalam Konfrensi daerah DPD PDIP Jawa Barat yang dilakukan Calon Ketua Termuda begitu dinamis dan tidak statis, dimana calon ketua bisa mempersuasif kader-kader partai yang ada di Kab/Kota di seluruh Jawa Barat. Bahkan sampai tingkat PAC pun ikut andil dan partisipasi dalam proses pencalonan calon ketua DPD PDIP Jawa Barat. Hal ini menandakan bahwasanya PDI Perjuangan adalah partai politik yang mengakomodir aspirasi-aspirasi dari tingkatan paling bawah.

Dalam proses komunikasi politik dalam Konfrensi daerah DPD PDIP Jawa Barat dengan menggunakan pendekatan Struktutral Partai dan Personal sangat memerlukan pesan politik dan diperlukannya sosialisasi terlebih dahulu dalam melakukan kedua pendekatan tadi sehingga aktor dapat memberikan stimulus pesan kepada DPC, PAC dan kaderkader partai agar dapat diterima serta didukung dalam proses pencalonan Ketua DPD PDIP Jawa Barat periode 2015-2020. Maka dapat dibuat model proses komunikasi politik calon ketua termuda dalam Konfrensi daerah DPD PDI Perjuangan Jawa Barat 2015, seperti yang dapat dilihat dari tabel sebagai berikut; 


\section{Gambar 4.1 \\ M odel Proses K omunikasi Politik Calon \\ $K$ etua DPD PDI Perjuangan Dalam \\ Konfrensi Daerah DPD PDI Perjuangan \\ J awa Barat Periode 2015-2020}

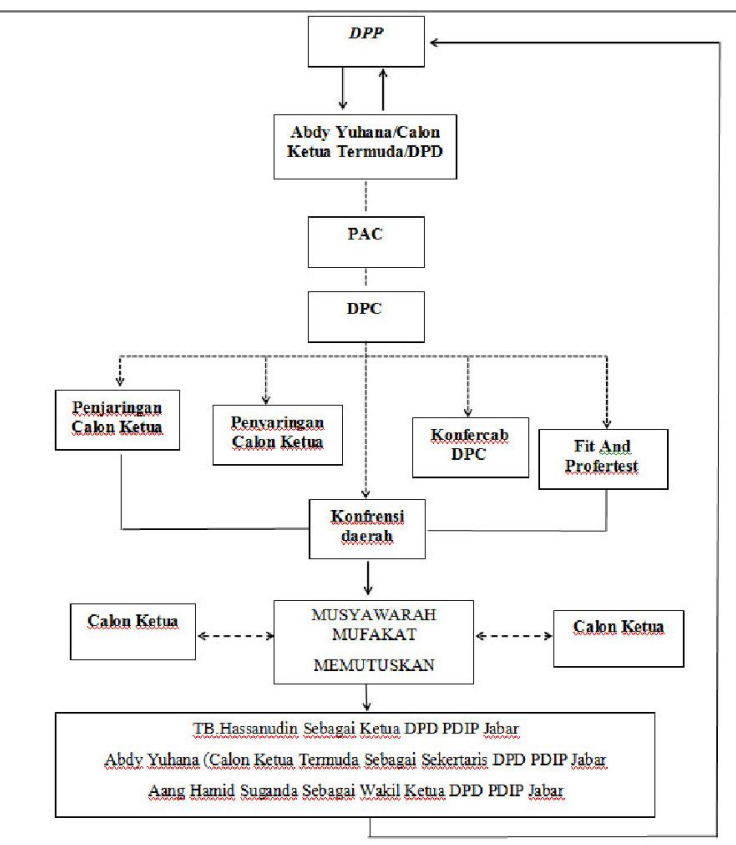

K eterangan Bagan M odel Proses K omunikasi Politik Calon $K$ etua Ter muda dalam K onfrensi daerah DPD PDI P J awa

DPP (Dewan Pimpinan Pusat) Barat.

Keterangan Bagan Proses Komunikasi Politik Calon Ketua Termuda dalam Konfrensi daerah DPD PDI P Jawa Barat.

DPP (Dewan Pimpinan Pusat)

DPD (Dewan Pimpinan Daerah)

DPC (Dewan Pimpinan Cabang)

PAC (Pengurus Anak Cabang)

Proses Komunikasi Politik

Dinamika Komunikasi Politik

\subsection{Realitas Komunikasi Politik Calon} Ketua DPD PDI Perjuangan Dalam Konfrensi Daerah DPD PDI Perjuangan J awa Barat Periode 2015-2020

Realitas yang terjadi dalam pemilihan calon ketua DPD PDI Perjuangan Jawa Barat. Menurut intrepretasi peneliti setelah melakukan penelitian dengan metode pengumpulan data melalui wawancara, obeservasi dan studi dokumentasi adalah bahwa ada dua realitas yang terjadi dalam Konfrensi daerah DPD PDI Perjuangan Jawa Barat. Pertama, Munculnya nama Abdy Yuhana (Calon Ketua Termuda) menjadi tiga besar calon ketua DPD PDI Perjuangan Jawa Barat atas rekomendasi DPP. Kedua, komunikasi politik calon ketua termuda dalam Konfrensi daerah DPD PDI Perjuangan Jawa Barat sehingga mendapatakan 69 suara rekomendasi dari DPC dan PAC.

Realitas dalam Konfrensi daerah DPD PDI Perjuangan Jawa Barat yang pertama Munculnya nama Abdy Yuhana (Calon Ketua Termuda) menjadi tiga besar calon ketua DPD PDI Perjuangan Jawa Barat atas rekomendasi DPP PDI Perjuangan. Dengan munculnya nama Abdy Yuhana menjadi tiga besar calon ketua DPD PDI Perjuangan Jawa Barat ini sangat tidak terduga, karena bagaimanapun juga beliau masih tergolong muda kalau peneliti bandingkan dengan kedua calon yang direkomedasikan oleh DPP PDI Perjuangan seperti TB.Hassanudin yang berumur 60 tahun dan Aang Hamid Suganda berumur 70 tahun.

Pencalonan Ketua DPD PDI Perjuangan Jawa Barat atau pencalonan Ketua DPC Perjuangan Kota/Kabupaten PDI Perjuangan sangat lah ketat dimana kematangan Ideologi dan disiplin dalam mengambil keputusan selalu dilakukan oleh DPP PDI Perjuangan guna menjadi acuan untuk semua calon ketua DPC dan DPD.

Sangat ketat nya kompetisi perncalonan DPD PDI Perjuangan Jawa Barat ini, kenapa bisa muncul nama Abdy Yuhana sebagai tiga besar calon ketua DPD PDI Perjuangan Jawa Barat. Padahal dari tujuh puluh (70) bakal calon ketua DPD PDI Perjuangan Jawa Barat melakukan berbagai tahapan yang sama untuk ditempuh, seperti Penjaringan, Penyaringan, dan tahap terakhir yaitu Konfrensi daerah.

Realitas komunikasi politik yang kedua adalah calon ketua termuda mendapat suara rekomendasi sebanyak 69 suara. Sangat ketatnya kompetisi dalam Pemilihan Calon Ketua DPD PDI Perjuangan Jawa Barat, hal ini didasari oleh keberhasil komunikasi politik yang dilakukan calon ketua termuda, terbukti calon ketua termuda berhasil menembus tiga besar dalam bursa calon ketua DPD PDI Perjuangan Jawa Barat 2015-2020 
bersama TB.Hassanudin dan Aang Hamid Suganda. Tentu dalam hal ini tidak bisa lepas dengan strategi komunikasi politik yang diterapkan oleh calon ketua termuda dan wacana calon ketua termuda saat mencalonkan ketua DPD PDI Perjuangan Jawa Barat.

Perolehan suara rekomendasi hingga 69 dari DPC dan PAC yang ada didaerah untuk calon ketua termuda dalam pencalonan ketua DPD PDI Perjuangan Jawa Barat merupakan suatu kepercayaan yang didapat oleh calon ketua termuda dari para kader-kader partai yang ada didaerah. Hal ini tidak bisa lepas dari komunikasi politik yang dibangun calon ketua termuda dalam menghadapi pemilihan calon ketua DPD PDI Perjuang Jawa Barat. Dengan menggunakan strategi komunikasi politik Secara Struktural Partai dan Personal merupakan suatu keberhasilan dalam melakukan komunikasi politik walaupun dalam praktek nya ada hambatan-hambatan yang terjadi dilapangan ketika melakukan komunikasi politik.

Tabel 4.1

SUARA REKOMENDASI UNTUK CALON KETUA TERMUDA

\begin{tabular}{|c|l|c|c|}
\hline \multirow{2}{*}{ NO } & \multirow{2}{*}{$\begin{array}{c}\text { NAMA DPC \& } \\
\text { PAC }\end{array}$} & \multicolumn{2}{|c|}{ SUARA } \\
\cline { 3 - 4 } & \multicolumn{1}{|c|}{$\begin{array}{l}\text { KOTA } \\
\text { BANDUNG }\end{array}$} & - & - \\
\hline 2 & KOTA CIMAHI & - & - \\
\hline 3 & BANDUNG & - & - \\
\hline 4 & $\begin{array}{l}\text { BANDUNG } \\
\text { BARAT }\end{array}$ & 1 & - \\
\hline 5 & CIANJUR & 1 & 7 \\
\hline 6 & KOTA BOGOR & - & - \\
\hline 7 & $\begin{array}{l}\text { KOTA } \\
\text { SUKABUMI }\end{array}$ & 1 & 1 \\
\hline 8 & BOGOR & - & 1 \\
\hline 9 & KOTA DEPOK & 1 & - \\
\hline 10 & KOTA BEKASI & - & - \\
\hline 11 & BEKASI & - & - \\
\hline 12 & KARAWANG & - & 2 \\
\hline 13 & PURWAKARTA & 1 & 1 \\
\hline
\end{tabular}

\begin{tabular}{|c|l|c|c|}
\hline 14 & CIREBON & 1 & 16 \\
\hline 15 & KOTA CIREBON & - & - \\
\hline 16 & INDRAMAYU & - & 3 \\
\hline 17 & SUMEDANG & 1 & - \\
\hline 18 & MAJALENGKA & - & - \\
\hline 19 & SUBANG & 1 & 9 \\
\hline 20 & KUNINGAN & - & - \\
\hline 21 & CIAMIS & 1 & 6 \\
\hline 22 & KOTA BANJAR & 1 & 1 \\
\hline 23 & TASIKMALAYA & - & - \\
\hline 24 & $\begin{array}{l}\text { KOTA } \\
\text { TASIKMALAYA }\end{array}$ & - & - \\
\hline 25 & GARUT & 1 & 11 \\
\hline 26 & SUKABUMI & - & - \\
\hline \multicolumn{2}{|c|}{ REKEKAP } & 11 & 58 \\
\hline \multicolumn{2}{|c|}{ KESELRUHAN } & & \\
\hline
\end{tabular}

Sumber : Arisp DPD PDIP J awa Barat

\section{Kesimpulan dan Rekomendasi}

\subsection{Simpulan}

Bab ini merupakan bagian terakhir dari hasil penelitian yang penulis lakukan. Dalam bab ini juga diuraikan mengenai simpulan penelitian dan saran-saran penulis Berdasarkan hasil penelitian pada Bab IV telah diangkat subfokus yang menjelaskan Dinamika K omunikasi Politik Calon K etua Termuda Dalam Konfrensi daerah DPD PDI Perjuangan J awa Barat maka dapat ditarik kesimpulan sebagai berikut :

1. Proses komunikasi politik konfrensi daerah DPD PDI Perjuangan Jawa Barat bahwa proses komunikasi politik terjadi pada saat konfercab, penjaringan dan penyaringan dan terakhir yaitu Konfrensi daerah yang terjadi begitu dinamis, dimana calon ketua termuda melakukan komunikasi politik dengan memanfaatkan hierarki struktural partai dan personal.

2. Realitas Komunikasi Politik DPD PDI Perjuangan Jawa Barat munculnya nama Abdy Yuhana sebagai calon ketua termuda dan suara rekomendasi calon ketua termuda mendapatkan 69 suara rekomendasi. Yang terjadi ketika sudah dilakukan nya Musyawarah mufakat 
terpilihlah TB.Hassanudin sebagai Ketua DPD PDI Perjuangan Jawa Barat, Abdy Yuhana sebagai Sekertaris DPD PDI Perjuangan Jawa Barat dan Aang Hamid Suganda sebagai Calon Ketua DPD PDI Perjuangan Jawa Barat.

\subsection{R ekomendasi}

Setelah penulis menyelesaikan pembahasan pada skripsi ini, maka pada bab penutup penulis mengemukakan saran-saran sesuai dengan hasil pengamatan dalam membahas skripsi ini.

1. Proses Komunikasi Politik Konfrensi daerah DPD PDI Perjuangan Jawa Barat harus dilakukan lebih terbuka lagi, dimana calon ketua bisa memaparkan visi-misinya terlebih dahulu sebelum diadakannya proses musyawarah mufakat, agar peserta mampu melihat kualitas calon.

2. Realitas komunikasi politik Konfrensi daerah DPD PDI Perjuangan Jawa Barat dalam prosesnya masih adanya ganguan dan hambatan misal adanya pengunduran hari dilaksanakannya konfrensi daerah hal tersebut sangat mempengaruhi jalannya konfrensi daerah termasuk dinamisnya namanama calon ketua yang bakal direkomendasikan oleh DPP PDI Perjuangan Jawa Barat.

\section{Daftar Pustaka}

Arifin, Anwar. Komunikasi Politik (Paradigma-Teori-Aplikasi-Strategi Komunikasi Politik Indonesia). Jakarta: PT. Balai Pustaka.2003

Budiarjo, Miriam. Dasar-Dasar Ilmu Politik. Jakarta: PT. Gramedia Pustaka Umum, 2008.
Cangara, Hafied. Komunikasi Politik. Jakarta: Kencana Prenada Media Group. 2004.

Creswell, J.W. Research design: Qualitative, quantitative, and mixed method approaches (2nd ed.). Thousand Oaks, Calif.: Sage Publications. 2003.

Creswell J.W. "Qualitative Inquiry and Research Design: Choosing Among Five Traditions" by J. W. Creswell. 1998.

Effendy, Onong Uchana, Ilmu Komunikasi Teori dan Praktek. Bandung: PT Remaja Rosdakarya. 2006.

Effendy, Onong Uchana, Komunikasi Politik; Konsep, Teori dan Strategi. Jakarta. PT Rajawali Pers , 2009.

Heryanto, G. Dinamika komunikasi politik. Jakarta: Lasswell Visitama. 2011.

Handoyo, Eko dkk. Etika Politik dan Pembangunan. Semarang: Widya Karya. 2010.

Herdiansyah, Haris. Metodologi Penelitian Kualitatif Untuk Ilmu-Ilmu Sosial, Jakarta, Salemba Humanika, 2010

Latif, Yudi. Negara Paripurna (Indonesian Edition). Gramedia Pustaka Utama, 2011.

Moleong, Lexy J. Metodologi Penelitian Kualitatif, Penerbit PT Remaja Rosadakarya Offset, Bandung, 2007

Mulyana, Deddy. Ilmu Komunikasi : Suatu Penghantar, Bandung, Remaja Rosdakarya, 2003.

Mulyana, Deddy. Komunikasi Politik, Politik Komunikasi, Bandung: Remaja Rosdakarya, 2013. 
Muhtadi, Asep Saeful. Komunikasi politik indonesia: Dinamika Islam PascaOrde Baru.Bandung: PT Remaja Rosdakarya. 2008.

Nimmo, Dan. Komunikasi Politik (Komunikator, Pesan, Media) Bandung: PT. Remaja Rosdakarya, 2004.

Rakhmat, Jalaluddin. Metode Penelitian Komunikasi, Bandung: Rosdakarya, 2007.

Rauf, Maswadi, Komunikasi Politik. Jakarta: Gramedia Pustaka Utama. 1993.

Rush, Michael dan Philip Althoff. Pengantar Sosiologi Politik. Jakarta: PT Grafindo Persada. 1997.

Santosa, Slamet., Dinamika Kelompok, Jakarta: Bumi Aksara. 2004.

Satori, Djam'an dan Komariah Aan, metodologi penelitian Kualitatif, Bandung: Alfabeta, 2009.

Sugiyono. Metodologi Penelitian Kuantitatif Kualitatif \& RND, Bandung, Alfabeta, 2010.

Wiryanto, Pengantar Ilmu Komunikasi. Jakarta, PT.Grasindo. 2004 